\title{
Lima Bean Downy Mildew: Impact, Etiology, and Management Strategies for Delaware and the Mid-Atlantic Region, U.S.
}

Lima bean (Phaseolus lunatus L.) has been an important crop grown for canning and freezing in the mid-Atlantic area of the United States since the nineteenth century (39). Three commercial classes of lima bean are used for processing: the smallseeded green baby lima, the small-seeded speckled lima, and the large-seeded Fordhook lima (Fig. 1). The green baby lima class comprises the vast majority of production in Delaware. Morphological, biochemical, and molecular evidence indicate at least two, and possibly three, sites of domestication of the lima bean in Central and South America $(30,31)$. The green baby and speckled lima classes derive from the Mesoamerican gene pool, whereas the Fordhook lima class derives from the Andean gene pool (49).

In 2005, lima bean grown for processing was planted on 6,475 hectares in Delaware, with production valued at $\$ 6,475,000$ (55). In that same year, 13,211 hectares of lima bean were grown in the United States, with California being the largest producer of lima bean and Delaware being second (1). Lima bean is considered to be the cornerstone crop of the vegetable processing industry in Delaware, and Delaware remains one of the few states that produce the crop (41).

In the mid-Atlantic states, lima bean is grown using conventional tillage practices and is planted in $76-\mathrm{cm}$ rows, generally after pea or small grain in June or July. Growers contract with processing companies for a certain acreage to be planted, and in most cases, the processing company performs the harvest mechanically using pod-stripper combines. Improvements to harvesters in recent years, including multibeater threshers and electrohydraulic sys-

Corresponding author: Thomas A. Evans, Department of Plant and Soil Sciences, University of Delaware, Newark, DE.

E-mail: tomevans@UDel.Edu

DOI: 10.1094/PDIS-91-2-0128

(c) 2007 The American Phytopathological Society tems, have increased the harvest recovery efficiency of the stripper heads for the one field pass harvesting process. Yields in Delaware generally increase with later planting dates, which are associated with higher rainfall and cooler days and nights in September and October, a time when these plants are flowering and setting pods (68). Depending on cultivar, flowers first form 35 days after planting, and peak flowering occurs at 60 days. Harvest occurs 80 to 90 days after planting for baby lima bean and 90 to 100 days after planting for Fordhook cultivars. While late planting dates result in fall flowering and a concomitant increase in yields under normal circumstances, environmental conditions in fall produce evening dews and leaf wetness that provide ideal conditions for the development of downy mildew caused by Phytophthora phaseoli Thaxt.

\section{History \\ of Lima Bean Downy Mildew}

Lima bean downy mildew was first reported by Thaxter in Connecticut in 1889 (60), and we continue to detect $P$. phaseoli in Delaware almost every growing season (29). Other published reports include detection in the Philippines (6), the former Soviet Union (57), Congo (now Zaire) (32), Puerto Rico (33), and Italy (5). Overseas reports of lima bean downy mildew

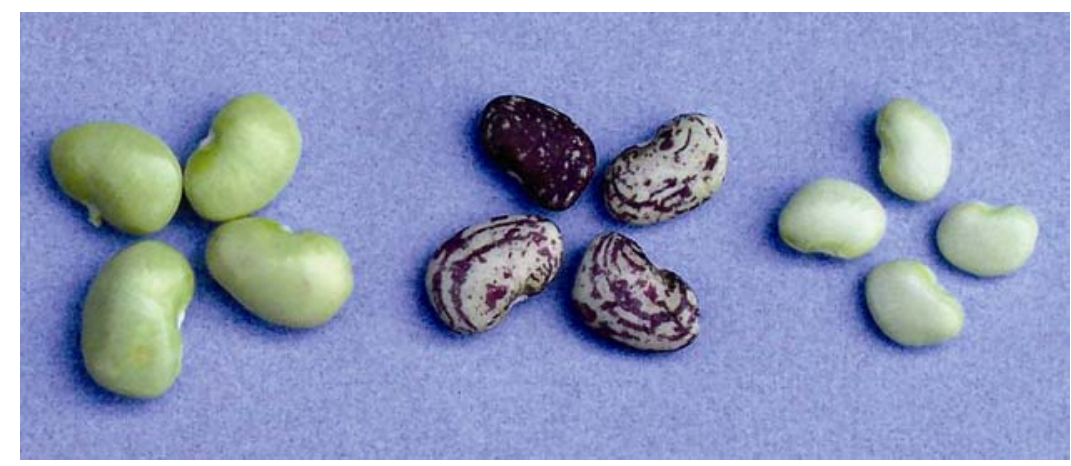

Fig. 1. Comparison of commercial classes of lima bean (Phaseolus lunatus) used by the vegetable processing industry; large-seeded Fordhook (left), small-seeded baby green lima bean (right), and small-seeded speckled lima bean (center). 

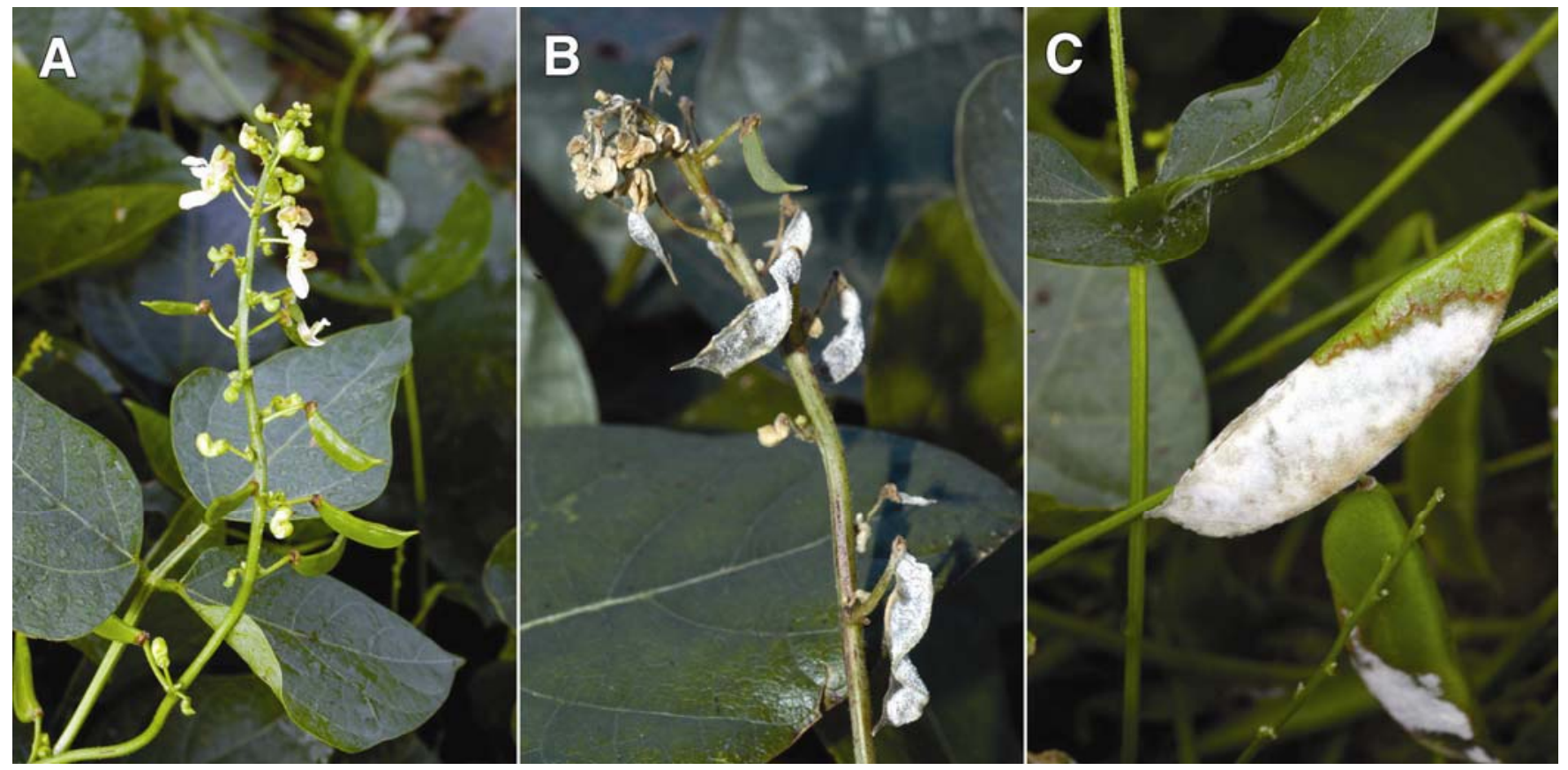

Fig. 2. Signs and symptoms of lima bean downy mildew caused by Phytophthora phaseoli: A, healthy flower racemes; B, infected flower racemes; $\mathrm{C}$, close-up of typical cottony mycelium and sporangia on flat pods.

lated $P$. phaseoli from Phaseolus vulgaris (navy bean) in West Virginia. Leonian did not report morphometric information about his isolate, so we cannot be certain of its identity.

In 1928, Clara (6) reported that an isolate of what was characterized as $P$. phaseoli produced varying levels of seedling infection and disease in eight plant species including Brassica juncea (L.) Czerniak (brown mustard), Hevea brasiliensis (H.B.K.) Muell. Arg. (para rubber), Lycopersicon esculentum L. (tomato), Phaseolus spp. (bean), Raphanus sativus L. (radish), Sandoricum indicum Cav. (santol), Solanum melongena L. (eggplant), and Vigna unguiculata subsp. sesquipedalis (L.) Verd. (sitao). All of the above "hosts" were reported to have infection confined to wounds, or produced slight rotting or damping-off of stems. However, the conditions used to produce infection were not stated. Since Clara (6) failed to provide information on the conditions used to promote disease development or detail symptom development and because of the limited and slightly different morphometric data provided for the isolate, we lack confidence that the isolate used was $P$. phaseoli and that the species reported were hosts. Clara (6) reported that the sporangia of the Philippine isolate averaged $35.7 \times$ $25.2 \mu \mathrm{m}$. This is somewhat different from our reported sporangial measurements of $39 \times 22 \mu \mathrm{m}$. Clara does not mention the length of sporangial pedicels for the isolate used. Pedicel length is an important morphological characteristic differentiating this Phytophthora species from others.

In 1951, Hyre and Cox (37) tested crop species for susceptibility to $P$. phaseoli, including $P$. lunatus, $L$. esculentum, and $P$. vulgaris, and found that only $P$. lunatus was susceptible, producing white downy growth of the pathogen. In 2002, Dominiak (21) carried out an extensive study of agricultural crops and weed species as alternate hosts of $P$. phaseoli. Of the 33 plant species, including $L$. esculentum, $P$. vulgaris, and $R$. sativus, and 20 weed species tested, only $P$. lunatus and $P$. limnensis (now regarded as $P$. lunatus) became infected.

\section{Development of Disease and Symptom Expression}

While the initial infection process of lima bean in the field is still unclear, flower racemes, shoot tips, petioles, small pods (pins) to mature pods of lima bean are the most susceptible plant organs (Figs. 2 and 3). In dew chamber studies, both hypocotyls and leaves are susceptible, but they play little role in disease progress in the field. Under ideal environmental conditions, pods are covered with white, cottony mycelial growth with abundant sporangia (Fig. 2), with a reddish band often surrounding the infected area (Figs. 2 and 4A). Infected pods become necrotic, dried, and eventually shrivel (Fig. 5). These symptoms may be used to distinguish $P$. phaseoli infections from the newly reported pathogen of lima bean, Phytophthora capsici (20), which produces no red margin. Mycelia and sporangia are more tightly appressed to the pods with $P$. capsici (Fig. 4B).

\section{Pathogen Description}

Phytophthora phaseoli was first described by Thaxter (60), amended by Clinton (7), and was described in Erwin and

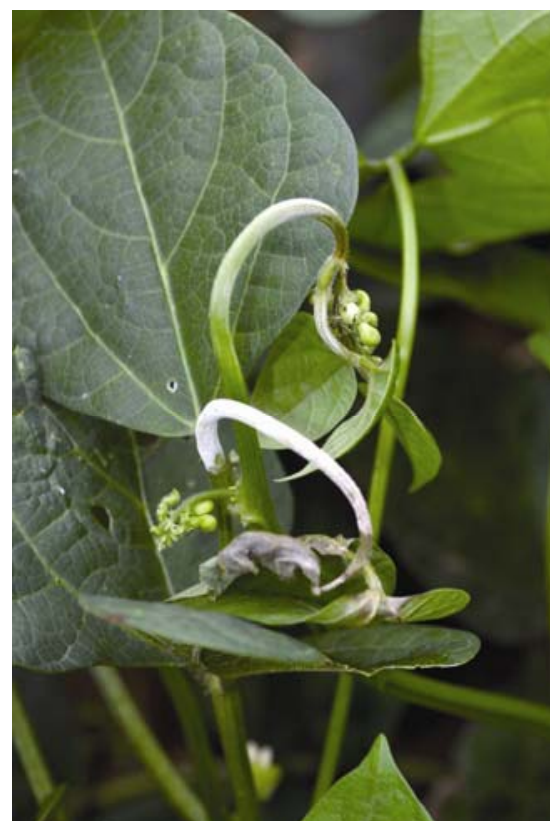

Fig. 3. Signs and symptoms of downy mildew of lima bean caused by Phytophthora phaseoli on petiole and shoots.

Ribeiro (27). P. phaseoli, as we have observed it, differs from the original description by Thaxter in 1889 , which also is the basis for the description in Erwin and Ribeiro. (Note that there is a typographical error in Erwin and Ribeiro for the average sporangial dimensions.) The primary difference is in the length of the pedicel, which ranges from 1 to $5 \mu \mathrm{m}$ for $P$. phaseoli, but is described by Thaxter as ranging from 5 to $20 \mu \mathrm{m}$. The sporangiophores are mostly simple, not sympodially branched. This could lead to some confusion and 
misidentification with $P$. capsici, which has a longer pedicel length and sporangiophores described as sympodially branched. Oospores are not produced abundantly on host tissue; rather, they are produced rarely or in response to fluctuations in temperature or drying of host tissue. Mycelium is branched, with no hyphal swellings or chlamydospores.

Sporangia are semi-papillate, oval to limoniform to elliptical with a truncate base consisting of a short pedicel (Fig. 6A). On lima bean tissue, sporangia average $39 \times$ $22 \mu \mathrm{m}$ with a range of 33 to $48 \times 18$ to 28 $\mu \mathrm{m}$, with an average length:breadth ratio of 1.8:1. On lima bean agar, sporangia are slightly smaller, averaging $34 \times 22 \mu \mathrm{m}$. The average length of the pedicel is 2.75 $\mu \mathrm{m}$ with a range of 1 to $5 \mu \mathrm{m}$. Simple sporangiophores average $310 \mu \mathrm{m}$ with a range of 140 to $525 \mu \mathrm{m}$. Sporangia are formed by swelling at the apex of the sporangiophore. A septation is formed when a sporangium is completely formed, resulting in release of the sporangium with the short pedicel where the attachment had been (Fig. 6A). Sporangia are caducous or deciduous, and direct germination is common, although zoospores may be produced and released. Sporangia are commonly found on agar as well as on plant tissue (Fig. 6B) and may be airborne or waterborne due to the cadu-

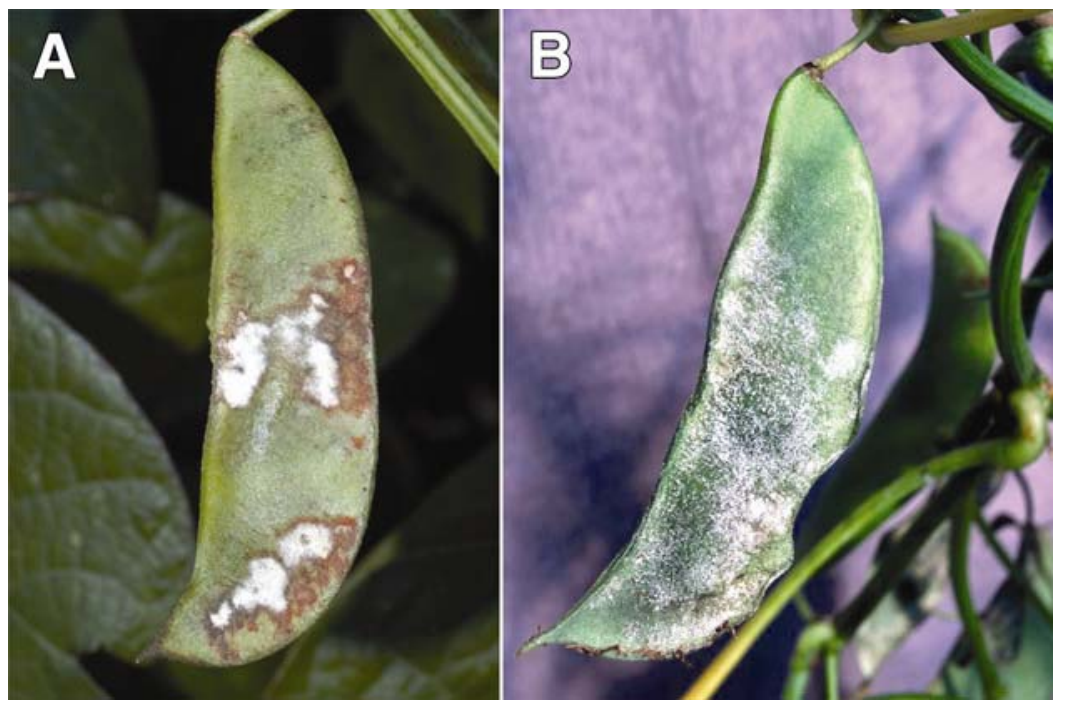

Fig. 4. A, Lima bean downy mildew caused by Phytophthora phaseoli, and B, lima bean pod blight caused by $P$. capsici. Note the cottony nature of mycelium and reddening of pods infected by $P$. phaseoli and the granular sugarlike appearance of mycelium on pods infected by $P$. capsici.

cous nature and short pedicel. P. phaseoli is homothallic with amphigynous antheridia. Oospores are formed in old culture plates and on plant tissue, but are not numerous.

Growth of isolates in culture is 6 to 9 $\mathrm{mm}$ per week at 18 to $20^{\circ} \mathrm{C}$ on frozen lima bean agar (4). A typical culture will grow radially 18 to $20 \mathrm{~mm}$ in 21 days from a mass transfer. Isolates do not survive longterm on agar plates, but survive several years in screw cap test tubes of sterile water containing autoclaved corn seed, hemp seed, or cucumber seed. Frozen lima bean agar is best for growth of isolates and sporangial production for inoculum. The optimum temperature for growth is 15 to $20^{\circ} \mathrm{C}$, but growth slows below $5^{\circ} \mathrm{C}$ or above $30^{\circ} \mathrm{C}$. Temperatures greater than 30 to $32^{\circ} \mathrm{C}$ may be lethal to the fungus (38). However, isolates of some races of the fungus survived temperatures of 35 to $38^{\circ} \mathrm{C}(19)$.

\section{Description of Physiological Races}

Downy mildew has been a major disease of lima bean grown in the humid eastern United States since the late 1880s. Presently, six physiological races of $P$. phaseoli, $\mathrm{A}, \mathrm{B}, \mathrm{C}, \mathrm{D}, \mathrm{E}$, and $\mathrm{F}$, are known to exist (19). A physiological race, hereafter referred to simply as race, is a subdivision of a pathogen species, particularly fungi, distinguished from other members of the species by specialization for pathogenicity in different host cultivars (42). The development of new races of $P$. phaseoli, and the epidemics that they have produced in the eastern United States, has been a major factor in the relocation of lima bean grow-

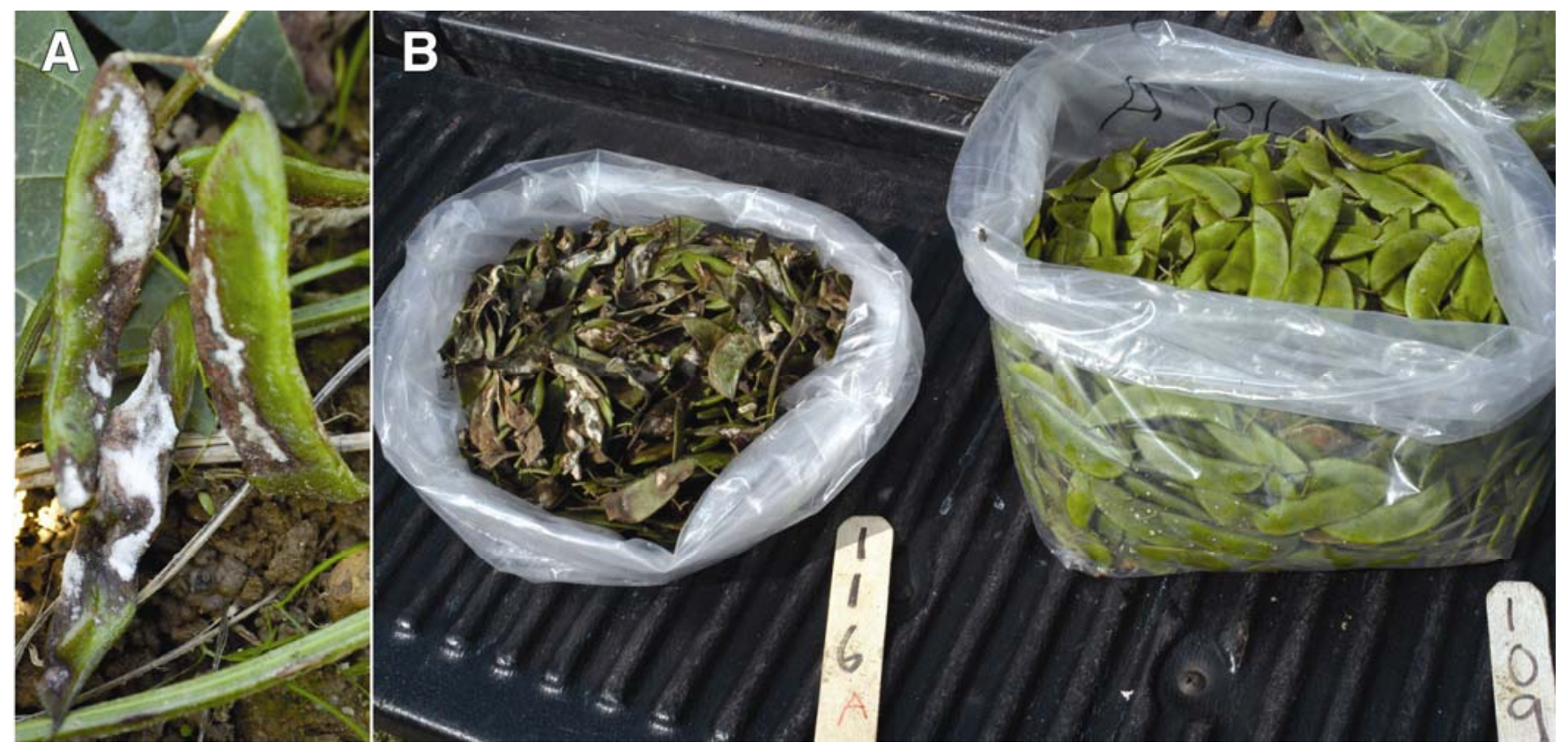

Fig. 5. Effect of Phytophthora phaseoli infections on lima bean pod production and color. A, Infected pods showing various degrees of drying and necrosis. B, Effect of $P$. phaseoli infections on yield from 10 feet of row of lima bean. Fewer, dry, discolored, and shriveled pods from infected plants (left, unsprayed control), and pods from healthy plants (right, sprayed with Ridomil Gold/Copper). 
ers and processors from Connecticut and New York to New Jersey, then to Delaware and Maryland (39).

Until 1958, one race, later designated A (67), was the only known race of the pathogen. In 1958, a second race of $P$. phaseoli, designated $\mathrm{B}$, was isolated from the lima bean cultivar Thaxter in New Jersey (63). In 1969, race $C$ was isolated from the lima bean cultivar Dover in New Jersey near the site of previous epidemics caused by race B (64). Race D of $P$. phaseoli was first detected in 1975 from lima bean in experimental plots in Beltsville, MD (61) and in Delaware in 1990 (T. A. Evans, personal observation). In 1995, race E was first detected in Delaware (28) and became the dominant race of the pathogen in the region by 2000 (19).

In 2000, race $\mathrm{F}$ was first detected in Delaware and Maryland (28), and by 2004 it had become the dominant race (29). Races A, B, C , D, E, and F of $P$. phaseoli, and the cultivars used to differentiate them, have been clarified by Wester (64), Thomas and Blount (61), Stavely (58), Kee et al. (41), and most recently by Davidson (19). The existing races can be differentiated by determining the susceptibility of five baby lima bean cultivars (Table 1 ).

\section{Survival and Dissemination of the Pathogen}

$P$. phaseoli has been reported to overwinter as oospores on infected lima bean refuse in the field but not as hyphae or sporangia (66). The pathogen is not known to be seed transmitted (8). Therefore, oospores of $P$. phaseoli are the most likely primary inoculum, with the secondary inoculum being sporangia (8). Oospores may produce germ tubes and infect the plant directly or may produce sporangia. Sporangia may produce germ tubes and directly enter the plant or produce motile zoospores that may be released to infect susceptible lima bean tissues (62). The sporangia are airborne and are released daily over a 3- to 4-h period, midday (54), with symptoms appearing about 7 to 10 days after infection.

\section{Measures for Disease Management}

Measures to manage downy mildew have focused on prediction of disease occurrence, chemical control, and resistance. In 1958, Hyre (36) developed a predictive model using temperature and rainfall to alert lima bean growers in the mid-Atlantic region when conditions were favorable for downy mildew. According to Hyre's model, which was one of the first forecasting models for plant epidemics in the United States, conditions were favorable when there were 7 days of mean temperature of $<26.1^{\circ} \mathrm{C}\left(79^{\circ} \mathrm{F}\right)$ but $>7.2^{\circ} \mathrm{C}\left(45^{\circ} \mathrm{F}\right)$, with a 7-day total rainfall of $>3.05 \mathrm{~cm}$ (36). However, less rain was required if there had been periods of heavy dew. If the criteria were met for seven consecutive days, a fungicide spray alert was issued because downy mildew was possible in 1 to 2 weeks. According to Hyre, the cycle was broken if temperatures exceeded $32.2^{\circ} \mathrm{C}\left(90^{\circ} \mathrm{F}\right)$.

Recent studies indicate that races $\mathrm{E}$ and $\mathrm{F}$ may be more tolerant to temperature extremes than races $\mathrm{A}$ or $\mathrm{B}$, with which Hyre would have worked (19). Races E and $\mathrm{F}$ appear to be capable of surviving temperatures as high as 35 to $38^{\circ} \mathrm{C}$, although comparisons are impossible, as isolates of races $\mathrm{A}, \mathrm{B}$, and $\mathrm{C}$ are no longer evident in the population (28). A leaf wetness duration of 4 to $6 \mathrm{~h}$ with concomitant nighttime temperatures of 15 to $20^{\circ} \mathrm{C}$ for as few as 5 days may provide ideal conditions to predict disease development (54).

The use of resistant cultivars remains the most cost effective method of managing downy mildew. Planting disease-resistant cultivars of baby lima bean has been the primary disease control strategy since 1948, when a lima bean breeding program for developing resistance to the downy mildew fungus was initiated in cooperation with the Long Island Vegetable Research Farm at Riverhead, NY (65). Early crosses to incorporate disease resistance into 'Early Thorogreen' and 'Fordhook 242' were made at the USDA Plant Industry Section, Beltsville, MD, in the spring of
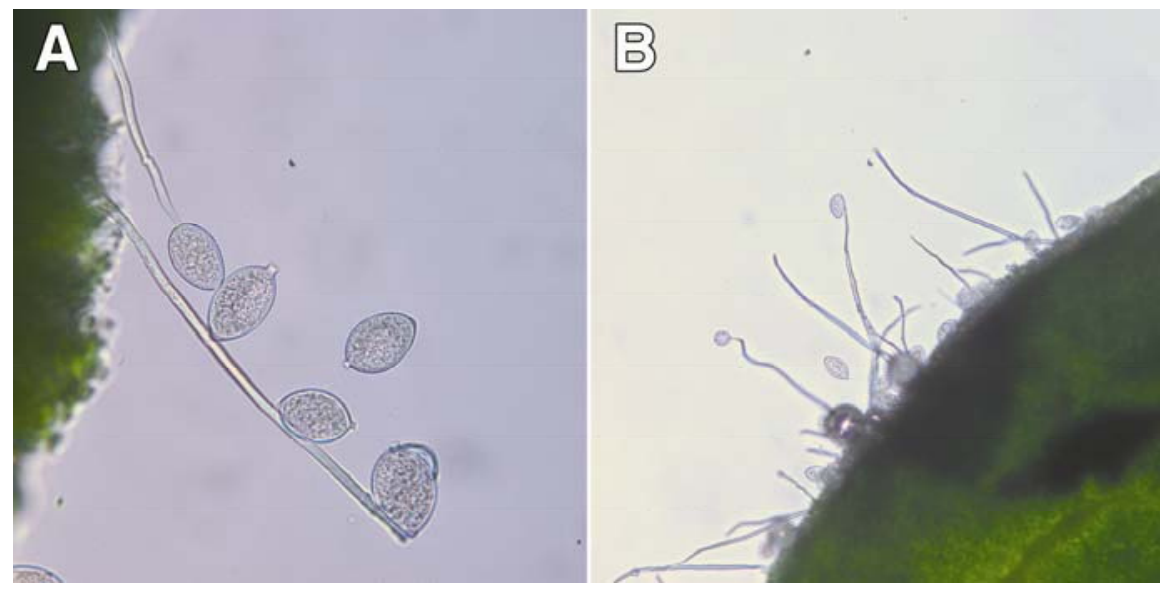

Fig. 6. Photomicrographs of sporangia of Phytophthora phaseoli. Image A $(\times 630)$ shows one sporangium attached to its sporangiophore and the characteristic shape and very short pedicel of a detached sporangium. Image B (×200) shows simple sporangiophores with sporangia attached on a leaf surface.

Table 1. Cultivar differential for determination of races of Phytophthora phaseoli

\begin{tabular}{lllllll}
\hline & \multicolumn{7}{c}{${\text { Races of } \boldsymbol{P}_{\text {phaseoli }} \text {. }}^{\text {Cultivars }}$} & A & B & C & D & E & F \\
\cline { 2 - 7 } Thaxter & $\mathrm{R}^{\mathrm{b}}$ & $\mathrm{S}$ & $\mathrm{S}$ & $\mathrm{S}$ & $\mathrm{S}$ & $\mathrm{S}$ \\
Bridgeton & $\mathrm{R}$ & $\mathrm{R}$ & $\mathrm{S}$ & $\mathrm{R}$ & $\mathrm{R}$ & $\mathrm{S}$ \\
$8-78$ & $\mathrm{R}$ & $\mathrm{R}$ & $\mathrm{R}$ & $\mathrm{R}$ & $\mathrm{S}$ & $\mathrm{R}$ \\
$184-85$ & $\mathrm{R}$ & $\mathrm{R}$ & $\mathrm{R}$ & $\mathrm{S}$ & $\mathrm{R}$ & $\mathrm{S}$ \\
M-15 & $\mathrm{R}$ & $\mathrm{R}$ & $\mathrm{R}$ & $\mathrm{R}$ & $\mathrm{S}$ & $\mathrm{R}$ \\
\hline
\end{tabular}

a Physiological races of $P$. phaseoli are distinguished by their ability to infect different cultivars of Phaseolus lunatus.

${ }^{\mathrm{b}}$ Reactions of isolates of $P$. phaseoli on different cultivars with $\mathrm{R}=$ resistant or no infection and $\mathrm{S}=$ infection and the development of cottony mycelium and sporangia. 
which seems to be conferred by either of two recessive resistance genes. It is likely that Maffei 15 and B2C carry the same resistance genes, since Maffei 15 is a selection from B2C (26).

Fungicide testing for control of downy mildew of lima beans began as early as 1897 when Bordeaux mixture was recommended for control (59). Later testing included copper fungicides and some of the organic fungicides (ferbam, Spergon, Phygon, Dithane D-14 plus zinc-sulfate and lime) (10). Copper was the preferred fungicide in the early days for control of downy mildew on Fordhook lima bean, but when 'Henderson Bush' (baby lima bean) became the primary cultivar grown in the mid-Atlantic area, it became evident that this cultivar was sensitive to copper fungicides. Phytotoxicity became such a serious problem that recommendations warned against using copper fungicides when disease levels were low to avoid yield losses associated with copper applications. The exception to that recommendation was when downy mildew threatened to become a serious problem late in the fall crop (2). By 1950, it was obvious that a new fungicide that did not damage the crop was needed to control downy mildew. Crossan et al. (9) reported success in controlling downy mildew without phytotoxicity with maneb or tri-basic copper sulfate when applications were timed with a disease forecast. Maneb became the industry stan- dard until 1989 when all of the EDBC fungicides were re-registered under the Federal Insect, Fungicide and Rodenticide Act (FIFRA), and lima bean was removed from the label. This action resulted in only copper fungicides being labeled for downy mildew. During the period when maneb and mancozeb were undergoing re-registration review, testing was initiated to determine efficacy of available fungicides for downy mildew control (44-46). Copper hydroxide fungicides were available in addition to chlorothalonil and metalaxyl. However, there were hindrances to obtaining labels for both those products for a minor crop such as lima bean, when the disease occurred in the relatively small mid-Atlantic area on only 6,070 hectares of late-planted lima beans. By the time reregistration occurred in 1989, disease-resistant cultivars were effective and downy mildew was not an issue. Copper hydroxide was determined to be more effective than tri-basic copper sulfate $(22,23)$ and became the only additional labeled fungicide that could be used to control downy mildew.

By 1998, it was clear that a new race of $P$. phaseoli had developed, genetic resistance was being overcome, and downy mildew was once again a problem. Fungicide testing was re-initiated at the University of Delaware to look at new fungicides for control of downy mildew. Early testing with metalaxyl (44-46) demonstrated that it was effective, so the new formulation of mefenoxam was included in subsequent tests along with new formulations of copper hydroxide and other copper compounds, strobilurin fungicides, and new fungicides with efficacy on oomycete fungi (Table 2). Of the products tested, mefenoxam, phosphorous acid salts, dimethomorph, pyraclostrobin, and azoxystrobin were the most efficacious. Table 3 is a compilation of the effective products tested to date and the number of years they were tested. As a result of our testing and cooperation with the USDA's IR-4 Project that supports the registration of fungicides for minor crops such as lima bean, a 24 (c) state special local needs registration was obtained in 2004 for the use of mefenoxam copper (Ridomil Gold/Copper, Syngenta Crop Protection) for control of lima bean downy mildew in Delaware and Maryland. Mefenoxam was labeled as an in-furrow or banded application at planting for Pythium damping-off, but the lack of residue data for mefenoxam applied to foliage did not permit registration for foliar application for downy mildew. Since the Environmental Protection Agency (EPA) would not accept the metalaxyl residue data, IR-4 in cooperation with Syngenta Crop Protection generated the residue data required for mefenoxam tolerance. Unfortunately, rates of Ridomil Gold or Ridomil Gold PC Granules applied at planting that were not

Table 2. Effective fungicides for control of downy mildew of lima bean, caused by Phytophthora phaseoli, based on fungicide testing from 1998 to 2006

\begin{tabular}{|c|c|c|c|}
\hline Fungicide & Common chemical name & FRAC grouping ${ }^{\mathrm{a}}$ & $\begin{array}{l}\text { Number of successful tests } \\
\text { (total number of times tested) }^{b}\end{array}$ \\
\hline Ridomild Gold Copper**c & Mefenoxam/copper hydroxide & Group $4+$ M1 & $8(8)$ \\
\hline Phostrol** & Phosphorus acid salts & Group 33 & $6(6)$ \\
\hline Champ DP, Kocide DF** & Copper hydroxide & Group M1 & $7(8)$ \\
\hline Cuprofix Disperss $* *$ & Basic copper sulfate & Group M1 & $1(1)$ \\
\hline Quadris & Azoxystrobin & Group 11 & $4(6)$ \\
\hline Headline (Cabrio, BAS500) & Pyraclostrobin & Group 11 & $3(5)$ \\
\hline
\end{tabular}

a FRAC = Fungicide Resistance Action Committee. Group M1 = multisite/inorganics, Group 4 = Phenylamide, Group $11=$ QoI, Group $15=$ Cinnamic acid, Group 33 = Phosphonates.

b A successful test is defined as one in which the fungicide treatment resulted in significantly better control than the check or yields were significantly higher than the check. In 2002, preventative and curative tests were conducted but the disease never developed, resulting in no data for that year, which is not included in this column.

c ** Currently labeled for downy mildew control through a Sec 3 (national use) or 24 (c) (special local need) label.

Table 3. Recommendations for fungicide applications, rates, and timing of application for downy mildew of lima bean caused by Phytophthora phaseoli in the mid-Atlantic States, U.S.

\begin{tabular}{|c|c|c|c|c|}
\hline \multirow[b]{2}{*}{ Fungicide } & \multicolumn{2}{|c|}{ Preventative } & \multicolumn{2}{|c|}{ Curative $^{a}$} \\
\hline & High disease & Low disease & High disease & Low disease \\
\hline Ridomil Gold/Copper & $\begin{array}{l}2 \mathrm{lb} 2 \times \\
7-14 \text { day interval }\end{array}$ & $2 \mathrm{lb} 1 \times$ & $\begin{array}{l}2 \mathrm{lb} 2 \times \\
7-14 \text { day interval }\end{array}$ & $\begin{array}{l}2 \text { lb } 1-2 \times \\
10-14 \text { day interval }\end{array}$ \\
\hline Phostrol & $\begin{array}{l}3-4 \text { pt } 1-2 \times \\
7-14 \text { day interval }\end{array}$ & $\begin{array}{l}2-4 \text { pt } 1-2 \times \\
7-14 \text { day interval }\end{array}$ & $\begin{array}{l}3-4 \text { pt } 2 \times \\
7-14 \text { day interval }\end{array}$ & $\begin{array}{c}4 \text { pt } 1 \times \text { or } 2-4 \text { pt } 2 \times \\
7-14 \text { day interval }\end{array}$ \\
\hline Copper & $\begin{array}{l}2 \mathrm{lb} 4 \times \\
7 \text {-day interval }\end{array}$ & $\begin{array}{l}2 \text { lb } 2 \times \\
7-10 \text { day interval }\end{array}$ & Not recommended & Not recommended \\
\hline
\end{tabular}

${ }^{a}$ Curative applications were initiated when disease was at very low incidence, less than $1 \%$ of pods and/or racemes infected. 
phytotoxic also did not provide seasonlong protection against downy mildew infection $(23,24,44,46)$. Following field testing with phosphorus acid salts (Phostrol, Nufarm Agriculture, USA) by Davey et al. $(14,16)$, Phostrol was also granted a 24 (c) registration for control of downy mildew in 2004. Currently, mid-Atlantic lima bean growers have the option of selecting copper fungicides, Ridomil Gold/ Copper, or Phostrol for downy mildew control (40). Testing is continuing to refine rates and timing of phosphorus acid salts for effective control under varying environmental conditions

The timing and number of fungicide applications for downy mildew control have always been important to growers to obtain maximum economic control. Testing conducted in 1948 demonstrated that downy mildew could be controlled with five weekly applications of Bordeaux mixture, tri-basic copper sulfate, Dithane Z-78, or Parzate (zineb) after the disease had appeared in the field (34). In 1950, Heuberger et al. (35) recommended weekly fungicide applications for as long as weather conditions remained favorable for infection. This usually required at least two applications to significantly reduce the number of infected pods. The development of the Hyre forecasting model (36) allowed growers and processors to predict periods favorable for downy mildew. Scouting was usually initiated at that time, and fungicide applications were delayed until the first symptoms of downy mildew were detected. Scouting large areas for a disease that only infects pods usually hidden by a dense canopy of healthy leaves sometimes resulted in undetected disease establishment, and often fungicides were unable to provide control in weather favorable for disease development. Growers used their best judgment by using the forecasting model and weather forecasts to time sprays, knowing the risk of not detecting the disease in a timely manner.

Fungicide testing for control of downy mildew of lima bean at the University of Delaware has had two objectives: (i) identify efficacious materials $(11,16,22-24,44-$ 46,48 ), and (ii) determine the most effective timing of their application (12$15,17,47,48)$. Our field studies have been done by inoculating lima bean plants in the field with specific races of the pathogen and providing ideal conditions for infection and disease development by exposing plants to prolonged dew periods created by timed overhead misting. By these actions, we greatly increase infection and disease incidence and have demonstrated that control of downy mildew can be achieved by either preventative or curative applications of efficacious fungicides provided the latter is made when the disease is first observed. The recommendations included in Table 3 are the result of our testing program to date and have been presented to the industry in extension meetings and publications (40). Growers currently make preventative applications of copper fungicides either alone or in combination with insecticides for pod-feeding insects. When conditions for downy mildew are favorable and outbreaks occur, applications of $\mathrm{Ri}$ domil Gold/Copper (mefenoxam) or Phostrol are made curatively to unsprayed fields or those where copper fungicides have been applied preventatively. Phostrol and Ridomil have been shown to be effective as early curative treatments but are recommended as preventative treatments. The risk of resistance development exists for Ridomil but not for Phostrol. Since Ridomil Gold/Copper contains copper hydroxide, which is active for control of downy mildew, two consecutive applications can be made but no more than two. Growers with downy mildew infected fields also have the option of using Phostrol exclusively or Ridomil Gold/Copper alternated with Phostrol to reduce the possibility of developing resistant strains of the fungus. No more than two sprays with mefenoxam would be needed in most seasons if applied at the first sign of disease, thus reducing selection pressure and resistance development.

\section{Current Status and Future Outlook}

Changes in the race of $P$. phaseoli have resulted in numerous epidemics over the past 100 years. Over the 20-year period from 1975 to 1994 , the dominant race of $P$. phaseoli was D, and few large epidemics occurred in the mid-Atlantic region because of the availability of resistant cultivars. In the 5-year period from 1995 to 2000 , two new races (E and F) were detected and became dominant in succession. This rapid change of race resulted in large epidemics and great economic losses to the industry. It is likely that the shifts in the dominant race were largely due to the changes in cultivars planted by growers over the same period. The development of additional races is a constant threat, and their monitoring is essential for the safety of the lima bean industry. While it is likely that $P$. phaseoli overwinters in the soil as oospores, the exact process by which the initial infection takes place each season is still unclear. Initial infections generally appear on flowers, young pods (pins), or larger, flat pods, but the process by which the pathogen progresses from an overwintering oospore in the soil to infection of the reproductive parts of the plant is not understood and needs to be clarified.

Currently, several fungicides are labeled and effective for control of downy mildew if applied in a timely manner. Ridomil Gold/Copper (mefenoxam/copper), Phostrol (phosphorus acid salts), and copper fungicides are currently labeled on lima bean and are effective. Other fungicides such as azoxystrobin and pyraclostrobin are labeled for control of anthracnose and soybean rust. Both of these products have activity against downy mildew that is not included on the label, but they could be labeled for downy mildew through the FIFRA section 24 (c) process, if needed. Other oomycete fungicides are being developed for late blight on potato and $\mathrm{cu}$ curbit downy mildew, and these candidate fungicides may prove to be valuable in the future should they be needed for downy mildew control. Copper fungicides currently available are good protectant fungicides when disease pressure is low to moderate, and they are good tank mix partners with mefenoxam and in rotation with other fungicides to prevent fungicide resistance. It has also been demonstrated that some formulations of copper may be phytotoxic under certain environmental conditions, but they do not reduce yield (21). A high risk of mefenoxam resistance developing in Phytophthora exists. However, as few applications are made during the growing season and not all acres of baby lima bean are treated, the overall risk may be considered moderate for $P$. phaseoli, but resistance to mefenoxam has been documented in P. phaseoli (25). The risk for the development of resistance to phosphorus acid fungicides, such as Phostrol, is considered low by the Fungicide Resistance Action Committee (FRAC).

One goal of the current lima bean breeding program at the University of Delaware is to improve cultivar resistance to the dominant or emerging races of $P$. phaseoli, particularly to combine resistance to both $\mathrm{E}$ and $\mathrm{F}$ in commercially viable baby and Fordhook lima bean cultivars. Other goals must include increasing heat tolerance, improving plant habit with respect to suitability for mechanical harvest, and increasing yield in both baby and Fordhook lima beans. Meeting these goals will help ensure the future of the lima bean and vegetable processing industry in the mid-Atlantic region.

\section{Acknowledgments}

We thank E. Ernest for her critical review of the manuscript and for supplying the image used in Figure 1, and L. Santamaria, J. F. Davey, J. D. Dominiak, and C. R. Davidson, graduate students in our laboratory, who have provided much of the data reported herein. Additional thanks to J. Sebastian and the University of Delaware Experiment Station personnel for their assistance in carrying out fieldwork. This research was supported by grants from the Delaware Department of Agriculture. Fungicide testing was supported by grants from IR-4, and major industry grants from BASF Corp, Nufarm Agriculture USA, and Syngenta Crop Protection.

\section{Literature Cited}

1. Agricultural Statistics Board. 2006. Vegetables 2005 summary. U.S. Dep. Agric. National Agricultural Statistics Service.

2. Anonymous. 1945. Copper injury to beans. Department of Plant Pathology, New Jersey Agric. Exp. Stn., Plant Disease Notes. 22(1):24. 
3. App, F. 1959. The history and economic importance of lima bean downy mildew disease. Proc. Am. Soc. Hortic. Sci. 33:473-476.

4. Calvert, O. H., Williams, L. F., and Whitehead, M. D. 1960. Frozen-lima-bean agar for culture and storage of Phytophthora sojae. Phytopathology 50:136-137.

5. Casarini, B., Quaglia, A., and Silvestri, G. 1960. La 'Peronospora' del 'Fagiolo di lima' (A Peronospora of lima bean). Phytopathol. Mediterr. 1:47-48.

6. Clara, F. M. 1928. A Phytophthora disease of Santol seedlings. Phillip. J. Sci. 35:411-425.

7. Clinton, G. P. 1906. Downy mildew, Phytophthora phaseoli Thaxt. of lima bean. Conn. Agric. Exp. Stn. Rep. 1905:278-303

8. Cox, R. S., and Hyre, R. A. 1951. Downy mildew of lima bean: Overwintering of the causal organism, Phytophthora phaseoli Thaxter, in Delaware. Trans. Peninsula Hortic. Soc.
41(1):58-64.

9. Crossan, D. F., Lloyd, P. J., Hyre, R. A., and Heuberger, J. W. 1957. Control of downy mildew of lima bean. Plant Dis. Rep. 41:156-159.

10. Cunningham H. S. 1947. Control of downy mildew of lima beans on Long Island. New York State (Geneva) Agric. Exp. Stn. Bull. 723.

11. Davey, J. F., Mulrooney, R. P., Evans, T. A., and Carroll, R. B. 2004. Evaluation of fungicides for control of downy mildew of baby lima bean, 2003. Fungicide and Nematicide Tests (on-line) Report 59:V104. DOI:10.1094/FN59. The American Phytopathological Society, St. Paul, $\mathrm{MN}$.

12. Davey, J. F., Mulrooney, R. P., Evans, T. A., and Carroll, R. B. 2004. Timing of preventative fungicide applications for the control of downy mildew of baby lima bean, 2003. Fungicide and Nematicide Tests (on-line) Report
59:V105. DOI:10.1094/FN59. The American Phytopathological Society, St. Paul, MN

13. Davey, J. F., Mulrooney, R. P., Evans, T. A. and Carroll, R. B. 2004. Timing of post-infection fungicide applications for the control of downy mildew of baby lima bean, 2003 Fungicide and Nematicide Tests (on-line) Report 59:V106. DOI:10.1094/FN59. The American Phytopathological Society, St. Paul, MN

14. Davey, J. F., Mulrooney, R. P., and Evans, T. A 2005. Timing of Phostrol fungicide applications for control of downy mildew of baby lima bean, 2004. Fungicide and Nematicide Tests (on-line) Report 60:V043. DOI:10.1094/FN60. The American Phytopathological Society, St. Paul, MN.

15. Davey, J. F., Mulrooney, R. P., Evans, T. A., and Carroll, R. B. 2005. Timing of protectant applications of fungicides for control of downy mildew of baby lima bean, 2004. Fungicide

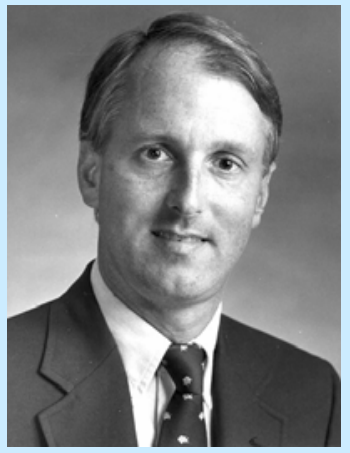

Thomas A. Evans

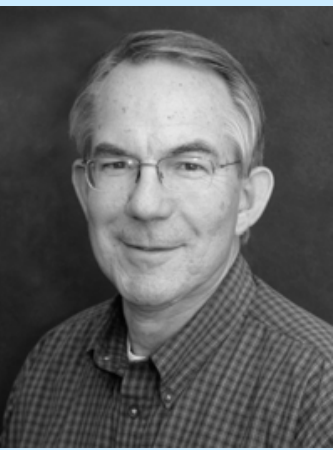

Bob Mulrooney
Dr. Evans is associate professor of plant pathology at the University of Delaware. He received his B.S. and M.S. in botany at Cal Poly, Pomona, and his Ph.D. in botany and plant pathology from Michigan State University in 1986. He started as a research plant pathologist working on diseases of vegetable crops at the University of Delaware's Research and Education Center in Georgetown. In 1989, he was promoted to assistant professor of plant pathology, and in 1995 to associate professor and moved his program to the Newark campus. For the past 10 years, his research group has focused on etiology, epidemiology, and control of downy mildew of lima bean. Dr. Evans has served APS as its Potomac Division's vice-president, president, councilor, and as an associate editor of Plant Disease. He is the co-editor of the second edition of the APS Press teaching publication, Laboratory Exercises for Introductory Plant Pathology, to be published in 2007.

Mr. Mulrooney is the extension plant pathologist at the University of Delaware. He received his B.S. in biology and M.S. in plant pathology from the University of Delaware in 1972 and 1974, respectively. He began as Kent County agricultural agent for the University of Delaware in 1974, and in 1977 became extension plant pathologist on the UD campus in Newark. His extension responsibilities include diagnostics of plant disease, including those caused by nematodes, and plant pathology education activities for commercial agronomic, vegetable, and ornamental diseases. He initiated the Nematode Diagnostic Service at UD in 1978. His applied research activities have focused on disease control of soybeans, wheat, lima beans, potatoes, and several ornamental crops. Mr. Mulrooney has been the chair of the APS Extension Committee and served the Potomac Division as president and vice-president.

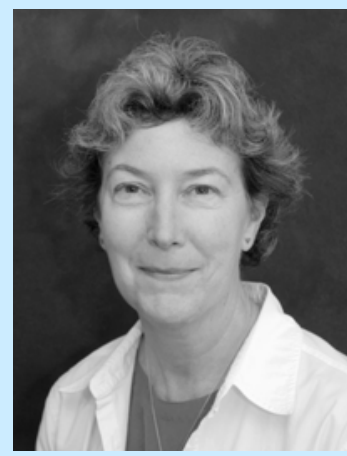

Nancy F. Gregory

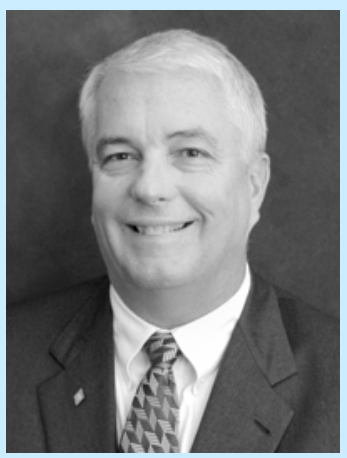

Ed Kee
Ms. Gregory is an extension associate in plant patholgy in the Department of Plant and Soil Sciences at the University of Delaware. She earned her M.S. in plant pathology from Penn State University in 1982, working on Fusarium wilt of chrysanthemum, and managed the lab of the Fusarium Research Center for 5 years. Following several years at the Tropical Research and Education Center in Homestead, FL, Nancy joined the Department of Plant and Soil Sciences at the University of Delaware in 1993. She is currently a plant disease diagnostician in the UD Plant Diagnostic Clinic in Newark. She teaches Introduction to the Fungi at the undergraduate and graduate levels, and assists with other courses and workshops. Nancy is an active participant in the National Plant Diagnostic Network, representing the Northeast region in the Information Technology/Diagnosician working group and National Database Committee.

$\mathrm{Mr}$. Kee is the extension vegetable crop specialist at the University of Delaware. He received his B.S. and M.S. in agriculture at the University of Delaware in 1973 and 1975, respectively. He started his career as Kent County Agricultural Agent for the University of Delaware in 1978, and in 1982 became State Vegetable Crops Specialist, working out of Research and Education Center in Georgetown. Currently, he serves as the vegetable crop specialist and the agricultural program leader. He has published or lectured on agricultural topics in the United States, Mexico, Germany, Hungary, Canada, and the Ukraine. He is author of "Saving Our Harvest: The History of the Mid-Atlantic Canning and Freezing Industry." Ed has authored or co-authored more than 30 articles in peerreviewed journals on subjects including horticulture, vegetable science, agricultural engineering, agricultural economics, and history. 
and Nematicide Tests (on-line) Report 60:V041. DOI:10.1094/FN60. The American Phytopathological Society, St. Paul, MN.

16. Davey, J. F., Mulrooney, R. P., Evans, T. A., and Carroll, R. B. 2005. Evaluation of fungicides for control of downy mildew of baby lima bean, 2004. Fungicide and Nematicide Tests (on-line) Report 60:V040. DOI:10.1094/FN60. The American Phytopathological Society, St. Paul, $\mathrm{MN}$.

17. Davey, J. F., Mulrooney, R. P., Evans, T. A., and Carroll, R. B. 2005. Timing of curative applications of fungicides for control of downy mildew of baby lima beans, 2004. Fungicide and Nematicide Tests (on-line) Report 60:V042. DOI:10.1094/FN60. American Phytopathological Society, St. Paul, MN.

18. Davey, J. F., Mulrooney, R. P., Evans, T. A., and Carroll, R. B. 2006. Timing of fungicide application for the control downy mildew of baby lima bean, 2005. Fungicide and Nematicide Tests (online) Report 61:V040. DOI: 10.1094/FN61. The American Phytopathological Society, St. Paul, MN.

19. Davidson, C. R. 2002. Studies of Phytophthora phaseoli, causal agent of lima bean downy mildew including race assessment, transformation, growth characteristics and varietal response. M.S. thesis. University of Delaware, Newark.

20. Davidson, C. R., Carroll, R. B., Evans, T. A., Mulrooney, R. P., and Kim, S. H. 2002. First report of Phytophthora capsaci infecting lima bean (Phaseolus lunatus) in the mid-Atlantic region. Plant Dis. 86:1049.

21. Dominiak, J. D. 2002. Downy mildew of lima bean: Alternate hosts, time of infection and control. M.S. thesis. University of Delaware, Newark

22. Dominiak, J. D., and Mulrooney, R. P. 2000. Fungicide evaluation for the control of downy mildew of baby lima beans, 1999. Fungicide and Nematicides Tests 55:141. The American Phytopathological Society, St. Paul, MN.

23. Dominiak, J. D., Mulrooney, R. P., and Evans, T. A. 2001. Fungicide evaluation for the control of downy mildew of baby lima beans, 2000. Fungicide and Nematicide Tests (online) Report 56:V17. DOI:10.1094/FN56. The American Phytopathological Society, St. Paul, MN.

24. Dominiak, J. D., Mulrooney, R. P., and Evans, T. A. 2002. Fungicide evaluation for the control of downy mildew of baby lima beans, 2001. Fungicide and Nematicide Tests (online) Report 57:V003. DOI:10.1094/FN57. The American Phytopathological Society, St. Paul, MN.

25. Dominiak, J. D., Mulrooney, R. P., Evans, T. A., Carroll, R. B., and Davidson, C. R. 2001. Sensitivity of Phytophthora phaseoli isolates to mefenoxam. (Abstr.) Phytopathology 91:S24.

26. Ernest, E. G., Kee, W. E., Jr., Santamaria, L., and Evans, T. A. 2006. Inheritance of resistance to lima bean downy mildew (Phytophthora phaseoli) and preliminary lima improvement efforts. Annu. Rep. Bean Improv. Coop. 49:37-38.

27. Erwin, D. C., and Ribeiro, O. K. 1996. Phytophthora phaseoli Thaxter. In: Phytophthora Diseases Worldwide. American Phytopathological Society, St. Paul, MN.

28. Evans, T. A., Davidson, C. R., Dominiak, J. D., Mulrooney, R. P., Carroll R. B., and Antonius, S. H. 2002. Two new races of Phytophthora phaseoli from lima bean in Delaware. Plant Dis. 86:813.

29. Evans, T. A., Mulrooney, R. P., and Santamaria, L. 2005. Development of races of Phytophthora phaseoli, the causal agent of downy mildew of lima bean (Phaseolus lunatus) and development of resistance. Annu. Rep. Bean Improv. Coop. 49:15-16.

30. Fofana, B, du Jardin, P, and Baudoin, J. P. 2001. Genetic diversity in the lima bean (Phaseolus lunatus L.) as revealed by chloroplast DNA (cpDNA) variations. Genet. Resour. Crop Evol. 48:437-445.

31. Gutiérrez Salgado, Gepts, A. P., and Debouck, D. G. 1995. Evidence for two gene pools of the lima bean, Phaseolus lunatus L., in the Americas. Genet. Resour. Crop Evol. 42:1528.

32. Hendrikx, F. L. 1939. Phytopathological observations at the station of Mulungu in 1938. Rev. Appl. Mycol. 19:329-330.

33. Henricksen, H. C. 1907. El cultivo de legumbres en Puerto Rico. Puerto Rico Agric. Exp. Stn. Bull. 7.

34. Heuberger, J. W. 1948. The downy mildew disease of Henderson Bush lima bean. Trans. Peninsula Hortic. Soc. 38(5):111-113.

35. Heuberger, J. W., Cox, R. S., and Hyre, R. A. 1950. Our present knowledge of the downy mildew disease of Henderson bush lima beans and its control in Delaware. Trans. Peninsula Hortic. Soc. 40(5):44-49.

36. Hyre, R. A. 1958. The development of a method for forecasting downy mildew of lima bean. Plant Dis. Rep. Suppl. 257:179-180.

37. Hyre, R. A., and Cox, R. S. 1952. Further studies in the physiology of Phytophthora phaseoli. (Abstr.) Phytopathology 42:468.

38. Hyre, R. A., and Cox, R. S. 1953. Factors affecting viability and growth of Phytophthora phaseoli. Phytopathology 43:419-425.

39. Kee, W. E. 1986. Lima beans show steady success in Delaware. Am. Veg. Grower 34:7879 .

40. Kee, W. E., Mulrooney, R. P., Caron, D., and Whalen, J. 2006. Commercial vegetable production recommendations-Delaware. Ext. Bull. 137, University of Delaware, Newark.

41. Kee, W. E., Jr., Glancey, J. L., and Wooten, T. L. 1997. The lima bean: A vegetable crop for processing. HortTechnol. 7:119-128.

42. Kirk, P. M., Cannon, P. F., David, J. C., and Stapler, J. A. 2001. Dictionary of the Fungi. 9th ed. CABI Publishers, Wallingford, Oxon, UK.

43. Leonian, L. H. 1925. Physiological studies of the genus Phytophthora phaseoli. Am. J. Bot. 12:444-498.

44. Mulrooney, R. P. 1981. Fungicide evaluations for control of downy mildew of baby lima beans, 1980. Fungicide and Nematicide Tests 36:53. The American Phytopathological Society, St. Paul, MN

45. Mulrooney, R. P. 1983. Fungicide evaluation for control of downy mildew of baby lima beans, 1982. Fungicide and Nematicide Tests 38:93. The American Phytopathological Society, St. Paul, MN

46. Mulrooney, R. P., and Carroll, R. B. 1982. Fungicide evaluation for control of downy mildew of baby lima beans, 1981. Fungicide and Nematicide Tests 37:62. The American Phytopathological Society, St. Paul, MN.

47. Mulrooney, R. P., Gregory, N. F., and Evans, T. A. 2006. Timing of curative fungicide applications for the control of downy mildew of baby lima beans, 2005. Fungicide and Nematicide Tests (on-line) Report 61:V127. DOI:10.1094/ FN61. The American Phytopathological Society, St. Paul, MN.

48. Mulrooney, R. P., Gregory, N. F., and Evans, T. A. 2006. Evaluation of fungicides for the control of downy mildew of baby lima bean, 2005 . Fungicide and Nematicide Tests (on-line) Report 61:V126. DOI:10.1094/FN61. The Ameri- can Phytopathological Society, St. Paul, MN

49. Nienhuis, J, Tivang, J., and Skroch, P. 1995. Genetic relationships among cultivars and landraces of lima bean (Phaseolus lunatus L.) as measured by RAPD markers. J Am. Soc. Hortic. Sci. 120:300-306.

50. Santamaria, L., Evans, T. A., Mulrooney, R. P., and Carroll, R. B. 2005. Evaluation of lima bean cultivars for resistance to downy mildew, 2004. Biological and Cultural Tests (on-line) Report 20:V014. DOI:10.1094/BC20. The American Phytopathological Society, St. Paul, $\mathrm{MN}$.

51. Santamaria, L., Evans, T. A., Mulrooney, R. P., and Carroll, R. B. 2005. Evaluation of USDA and CIAT lima bean germplasm accessions for resistance to downy mildew, 2004. Biologica and Cultural Tests (on-line) Report 20:V013. DOI:10.1094/BC20. The American Phytopathological Society, St. Paul, MN.

52. Santamaria, L., Evans, T. A., Mulrooney, R. P., and Carroll, R. B. 2006. Evaluation of lima bean cultivars for resistance to downy mildew, 2005. Biological and Cultural Tests (on-line) Report 21:V014. DOI:10.1094/BC21. The American Phytopathological Society, St. Paul, MN.

53. Santamaria, L., Evans, T. A., Mulrooney, R. P. and Carroll, R. B. 2006. Evaluation of USDA and CIAT lima bean germplasm accessions for resistance to downy mildew, 2005. Biological and Cultural Tests (on-line) Report 21:V013. DOI:10.1094/BC21. The American Phytopathological Society, St. Paul, MN.

54. Santamaria, L., Mulrooney, R. P., and Evans, T. A. 2005. Epidemiological studies of downy mildew of lima bean caused by Phytophthora phaseoli. Annu. Rep. Bean Improv. Coop. 49:17-18.

55. Scuse, M. T., and Cadwallader, C. L. 2005 Delaware agricultural statistics summary for 2004. Delaware Dep. Agric., Dover, DE.

56. Smith, C. O. 1904. Mildew of lima bean. Del. Agric. Exp. Stn. Bull. 63:23-24

57. Speschnew, N. N. 1897. Les parasites vegetaux de la Cakhetie. Arb. Bot. Gart. Tiflis 2 .

58. Stavely, J. R. 1991. Lima bean (Phaseolus lunatus L.) development at Beltsville. Annu. Rep. Bean Improv. Coop. Ann. Rep. 34:155156.

59. Sturgis, W. C. 1897. The mildew of lima beans. Connecticut Agric. Exp. Stn. Rep. 21:159-166.

60. Thaxter, R. 1889. A new American Phytophthora. Bot. Gaz. 14:273-274.

61. Thomas, C. A., and Blount, V. L. 1976. Race D of Phytophthora phaseoli. Plant Dis. Rep. 60:308

62. Walker, J. C. 1952. Downy mildew of lima bean. In: Diseases of Vegetable Crops. McGraw-Hill, New York.

63. Wester, R. E. 1968. New lima beans resistant to "B" strain of Phytophthora phaseoli. Plant Dis. Rep. 52:563-564.

64. Wester, R. E. 1970. A new race of downy mildew on lima beans. Phytopathology 60:1856.

65. Wester, R. E., and Cetas, R. C. 1959. Breeding lima beans for resistance to downy mildew. Plant Dis. Rep. Suppl. 257:181-182.

66. Wester, R. E., Goth, R. W., and Drechsler, C. 1966. Overwintering of Phytophthora phaseoli. Phytopathology 56:95-97.

67. Wester, R. E., and Jorgensen, H. 1959. A new race of Phytophthora phaseoli from lima beans. Plant Dis. Rep. 43:184-186.

68. Wooten, T. L. 1995. The effects of heat stress on retention and abscission of lima bean reproductive structures. M.S. thesis. University of Delaware, Newark. 